\title{
Effect of Pure and Mixed Suspensions of Virulent and Heterologous Isolates of Xanthomonas campestris on the Infectivity of the Inoculum on Two Species of Phaseolus ${ }^{1}$
}

\author{
Mildred Zapata ${ }^{2,3}$
}

ABSTRACT

The virulence of Xanthomonas campestris pv. phaseoli (Xcp) in mixed suspensions with a closely related heterologous soybean pathogen of $X$. campestris pv. glycines $(\mathrm{Xcg})$ was studied. Differences produced on pods by inoculation of mixed suspensions of $X_{c p}$ depended on host susceptibility and on the relative proportion in the suspension. Suspensions of Xcp mixed with Xcg showed decreased symptom development which did not depend on host susceptibility, or on the relative proportion of the pathogens in the suspension.

\section{INTRODUCTION}

Many inoculation techniques have been utilized to identify sources of resistance to Xanthomonas campestris pv. phaseoli (E. F. Smith) Dowson $(\mathrm{Xcp})(=X$. phaseoli), but the wide range of strain virulence on beans complicated such studies. For this reason, horizontal resistance seems to be one of the best measures of control for this pathogen. In order to identify germplasm with this resistance, suspensions containing strain mixtures of the pathogen have been used for inoculation by several workers $(4,11)$. However, there has been a lack of information about the effect on the inoculum infectivity when several strains are used in mixed suspensions in the laboratory.

A first step of defense in a plant might be the capacity to maintain an epiphytic flora antagonistic to the pathogen. Teliz and Burkholder (18) found that the Xanthomonads were more sensitive than the Pseudomonads to $P$. fluorescens obtained in dilution plates as contaminants during isolation of $X$. fuscans from diseased bean plants. In addition, various forms of antagonism, such as bacteriocin production (17) may affect the viability of different strains in the inoculum.

The objectives of this study were 1) to determine the effect on virulence of the inoculum when two of the most virulent isolates, $X$. c. pv. phaseoli (Xcp) and/or X. c. pv. phaseoli fuscans (Burkh.) Starr and Burkh. (Xcpf)

${ }^{1}$ Manuscript submitted to Editorial Board September 10, 1984.

${ }^{2}$ Assistant Phytopathologist, Department of Crop Protection, College of Agriculture Sciences, University of Puerto Rico, Mayagüez, Puerto Rico.

${ }^{3}$ This research was supported in part by contract AID-ta-C-1296, Title XII CRSP, "Improvement of Bean Production in the Dominican Republic through Breeding for Multiple Disease Resistance in the Preferred Standard Cultivars" and was carried out at the Tropical Agriculture Research Station (TARS), USDA/ARS, Mayagüez, Puerto Rico. 
(=X. phaseoli var. fuscans) were mixed in suspension in different proportions and inoculated on pods of the two species, Phaseolus vulgaris $\mathrm{L}$. (common bean) and $P$. coccineus $\mathrm{L}$. (scarlet runner bean), and 2) to determine the effect of $X . c$. pv. glycines (Xcg), an isolate heterologous on bean but closely related to Xcp and Xcpf, on infectivity of Xcp and/ or Xcpf, pods of $P$. vulgaris and $P$. coccineus, and on leaves of $P$. vulgaris.

\section{MATERIALS AND METHODS}

\section{BACTERIAL ISOLATES}

The isolates used belong to the bacterial collection at the USDA Tropical Agricultural Research Station (TARS), Mayagëz, Puerto Rico. Isolates $X$. campestris pv. phaseoli $(\mathrm{Xcp}) 820$ and $X$. campestris pv. phaseoli fuscans (Xcpf) 144, were selected for their high virulence on $P$. vulgaris (21). Isolate $X$. campestris pv. glycines (Xcg) 907 was selected because it is avirulent on $P$. vulgaris and is closely related to $\mathrm{Xcpf}$.

The pathogens were cultured on YDC agar medium containing $10 \mathrm{~g}$ dextrose, 2.5 g calcium carbonate, and $20 \mathrm{~g}$ agar per liter. The cultures were maintained at $26^{\circ} \mathrm{C}$ for $48 \mathrm{~h}$. The cell suspension was prepared with sterilized distilled water and standardized to $10^{9} \mathrm{cells} / \mathrm{ml}$ with a spectrophotometer at $625 \mathrm{~nm}$ and $10 \%$ transmission.

\section{PLANT MATERIAL}

Phaseolus vulgaris pods. The cultivars used were La Vega (black seed) and W-117 (white seed). The seeds were treated with streptomycin powder and planted in $15-\mathrm{cm}$ plastic pots containing a sterile soil mixture. Twenty-five plants were maintained in the greenhouse until six to 11 uniform green pods were collected for each treatment.

The four bacterial suspensions tested were pure suspensions of Xcp and $\mathrm{Xcg}$, and mixed suspensions of $\mathrm{Xcp} / \mathrm{Xcg}$ in proportions of 1:4 and 4:1 (v:v).

Phaseolus coccineus pods. Seven selections of $P$. coccineus grown under greenhouse conditions, which showed relatively good pod set in the second cycle of a recurrent selection program, were used for testing. These selections were 5a-1, 11b-3, 3d-1, 3a2P, 19a-3, 12b-1, and 22L-1. Phaseolus vulgaris cv. La Vega was included as the check.

Nine treatments with six repetitions were tested in three replications. The treatments included pure suspensions of $\mathrm{Xcp}, \mathrm{Xcpf}$ and $\mathrm{Xcg}$, and mixed suspensions of $\mathrm{Xcp} / \mathrm{Xcpf}, \mathrm{Xcp} / \mathrm{Xcg}, \mathrm{Xcpf} / \mathrm{Xcg}, \mathrm{Xcg} / \mathrm{Xcp}$, and $\mathrm{Xcg} / \mathrm{Xcpf}(1: 4, \mathrm{v}: \mathrm{v})$. 


\section{INOCULATION OF PODS}

The pods were washed by agitation with water in plastic bags and placed on moist paper towels on sterile aluminum trays. Three replications per plant selection were used.

The needle-scratch-inoculation method was used for this study because it gave the most uniform and rapid results according to previous research (22). The inoculation method consisted of depositing $0.01 \mathrm{ml}$ of bacterial suspension on the distal part of a pod and then scratching the pod surface with two dissecting needles $2 \mathrm{~mm}$ apart. For control, the proximal section of the pod was scratched in a similar manner but without the inoculum. The pods were incubated for 7 days in environmental chambers at $27^{\circ} \mathrm{C}$. Daylength was maintained for 12 hours with fluorescent lamps at 3228 lux.

\section{EVALUATION OF SYMPTOMS ON PODS}

Water-soaking and callous formation. The scale used for the watersoaked symptom was $1=$ no water-soaking, $2=$ narrow border of watersoaked tissue $\pm 1 \mathrm{~mm}, 3=$ water-soaked area of $2-3 \mathrm{~mm}$ wide, $4=$ watersoaked in round spot, 5 = water-soaked reaching the pod suture.

The scale used for callous formation was $1=$ no callous, $2=$ spongy tissue $\pm 1 \mathrm{~mm}, 3=$ spongy tissue $2-3 \mathrm{~mm}$ wide, $4=$ spongy tissue $3-4$ $\mathrm{mm}, 5=$ callous tissue opens $3 \mathrm{~mm}$ or more and raises the tissue (20).

\section{INOCULATION ON $P$. VULGARIS LEAVES}

Bacterial blight resistant germplasm from CIAT (13 lines) and Cornell University (12 lines) were tested and compared with La Vega (P R.). Four bacterial suspensions were tested: pure suspensions of $\mathrm{Xcp}, \mathrm{Xcpf}$ and $\mathrm{Xcg}$, and a mixture of Xcp, Xcpf and Xcg at 1:1:1 (v:v). The youngest and full expanded trifoliolate leaf of plants at the flowering stage was inoculated using the multineedle technique (22). Ten repetitions per replicate (3) were used. The inoculation technique consisted of a multineedle perforator on a foam cushion, and then rubbing of the leaves while they were submerged in the bacterial suspension. Each suspension was standardized to contain $10^{9}$ cells $/ \mathrm{ml}$. Data were recorded at 7 and 14 days after inoculation.

The scale of symptom expression was $1=$ resistant, $2=$ slightly susceptible, $3=$ moderately susceptible, $4=$ susceptible, and $5=$ highly susceptible.

\section{RESULTS}

The water-soaking and callous symptoms induced by Xcpf on inoculated pods of $P$. vulgaris cv. La Vega and W-117 were clearly expressed 
and showed significant diferences when compared with pods inoculated with Xcg, Xcpf/Xcg and Xcg/Xcpf, which were not significantly different between each other (table 1). This indicates an antagonistic effect in relation to the symptoms developed on pods when Xcfp was mixed with $\mathrm{Xcg}$ in the proportions 4:1 and 1:4 (v:v). There was no significant difference in the infection index between the treatment containing a pure suspension of $\mathrm{Xcg}$ and the mixed suspension of Xcg with Xcpf (table 1). There were no significant differences between $\mathrm{Xcp}$ and Xcpf with

TABLE 1.-Reaction of pods of Phaseolus vulgaris inoculated with four different suspensions of Xanthomonas campestris

\begin{tabular}{llcc}
\hline \multirow{2}{*}{ Cultivars } & & \multicolumn{2}{c}{ Reactions $^{1}$} \\
& & $\frac{\text { Water-soaked }}{\overline{\mathrm{x}}}$ & $\frac{\text { Callous }^{2}}{\overline{\mathrm{x}}}$ \\
\hline La Vega & $\mathrm{Xcpf}$ & $1.64^{* * 3}$ & $1.64^{* *}$ \\
& $\mathrm{Xcpf} / \mathrm{Xcg}$ & 1.06 & 1.06 \\
$\mathrm{Xcg}$ & 1.06 & 1.06 \\
$\mathrm{Xcg} / \mathrm{Xcpf}$ & 1.06 & 1.06 \\
$\mathrm{Xcpf}$ & $1.42^{* * *}$ & $1.50^{* *}$ \\
& $\mathrm{Xcpf} / \mathrm{Xcg}$ & 1.08 & 1.08 \\
$\mathrm{Xcg}$ & 1.06 & 1.06 \\
& $\mathrm{Xcg} / \mathrm{Xcpf}$ & 1.07 & 1.07 \\
\hline
\end{tabular}

${ }^{1}$ Reactions 7 days after inoculation: Water-soaked: The water-soaked area bordering the scratch was rated as follows: $1=$ no water-soaking; 2 = narrow border of water-soaked tissue $\pm 1 \mathrm{~mm} ; 3$ = water-soaked area of $2-3 \mathrm{~mm}$ wide; 4 = water-soaked in round spot; 5 = water-soaked reaching the pod suture. Callous: $1=$ no callous; $2=$ spongy tissue \pm 1 $\mathrm{mm} ; 3=$ spongy tissue $2-3 \mathrm{~mm}$ wide; $4=$ spongy tissue $3-4 \mathrm{~mm} ; 5=$ callous tissue opens 3 $\mathrm{mm}$ or more and raises the tissue.

${ }^{2}$ Bacterial suspensions of approximately $10^{9}$ cells per ml. Proportion of mixed suspension: 1:4 (vol:vol), each figure representing the bacterial isolates, respectively; $\mathrm{Xcpf}=X$. campestris pv. phaseoli (fuscans); $\mathrm{Xcg}=X$. campestris pv. glycines.

${ }^{3}$ In each variety of the $\mathrm{Xcpf}$ treatment was compared with the other treatments using the $t$ test at probabilities of $0.01^{* *}$.

respect to the infection index produced on inoculated pods, but at least one or both isolates differed significantly from Xcg on $P$. vulgaris and $P$. coccineus pods. Neither Xcg nor the check treatment produced any visible symptoms in inoculated pods.

The mixed suspension of Xcp and Xcpf in proportions 4:1 and 1:4 (v:v) on pods showed no synergistic or antagonistic effect when they were compared with the pure suspensions of Xcp and Xcpf.

The mixed suspensions of $\mathrm{Xcp} / \mathrm{Xcg}$ and $\mathrm{Xcpf} / \mathrm{Xcg}$ in the proportions 4:1 and 1:4 (v:v) were not significantly different from the pure suspension of Xcg with respect to the infection index developed on the pod, but were different from those of $\mathrm{Xcp} / \mathrm{Xcpf}$ (table 2). 
Symptoms produced by the inoculation of mixed suspensions of Xcp/ Xcpf apparently depended on host susceptibility to each pathogen and on the relative proportion of each pathogen in the suspension (table 2 , IIIa and IIIb). No synergistic or antagonistic effect was found to be related to the combination of the agents. On the other hand, mixed suspensions of $\mathrm{Xcp} / \mathrm{Xcg}$ and $\mathrm{Xcpf} / \mathrm{Xcg}$ showed an antagonistic effect on

TABLE 2.-Bacterial treatment comparison for the determination of an antagonistic effect of mixed suspensions of Xanthomonas campestris on pods

\begin{tabular}{|c|c|c|c|c|c|c|c|c|}
\hline & \multirow{2}{*}{$\begin{array}{l}\text { P. vulgaris } \\
\mathrm{LV}^{1}\end{array}$} & \multicolumn{7}{|c|}{ P. coccineus } \\
\hline & & $5 a-1$ & $11 \mathrm{~b}-3$ & $3 \mathrm{~d}-1$ & $3 a-2 P$ & $19 a-3$ & $12 \mathrm{~b}-1$ & $22 \mathrm{~L}-1$ \\
\hline \multirow{2}{*}{$\begin{array}{l}\text { I. } \mathrm{Xcp} / \mathrm{X} \mathrm{Cg}^{2} \\
\mathrm{Xcg} / \mathrm{X} \mathrm{cp}\end{array}$} & $1.00^{* * 3}$ & $1.00^{* *}$ & $1.00^{* * *}$ & $1.00^{* *}$ & $1.00^{* *}$ & 1.00 & 1.00 & 1.00 \\
\hline & $1.00^{* *}$ & $1.00^{* *}$ & $1.00^{* *}$ & $1.00^{* *}$ & $1.00^{* *}$ & 1.00 & 1.00 & 1.00 \\
\hline $\mathrm{Xcp}$ & 3.00 & 2.00 & 2.00 & 1.88 & 1.83 & 1.50 & 1.33 & 1.33 \\
\hline II. Xcpf/Xcg & $1.00^{* *}$ & $1.00^{* *}$ & $1.00^{* *}$ & 1.00 & $1.00^{* *}$ & $1.00^{* *}$ & $1.00^{* *}$ & $1.00^{* *}$ \\
\hline $\mathrm{Xcg} / \mathrm{Xcpf}$ & $1.00^{* *}$ & $1.00^{* *}$ & $1.00^{* *}$ & 1.00 & $1.00^{* *}$ & $1.00^{* *}$ & $1.00^{* *}$ & $1.00^{* *}$ \\
\hline Xcpf & 2.00 & 2.00 & 2.00 & 1.50 & 2.00 & 2.50 & 1.67 & 2.17 \\
\hline IIIa. Xcp/Xcpf & 3.00 & 1.75 & 2.00 & 2.50 & 1.50 & 1.50 & 1.17 & 2.00 \\
\hline $\mathrm{Xcpf} / \mathrm{Xcp}$ & $1.75^{*}$ & 2.00 & 2.00 & 2.17 & 1.83 & $2.90^{*}$ & 1.83 & 2.00 \\
\hline $\mathrm{Xcp}$ & 3.0 & 2.00 & 2.00 & 1.88 & 1.83 & 1.50 & 1.33 & 1.33 \\
\hline IIIb. Xcpf/Xcp & 1.75 & 2.00 & 2.00 & 2.17 & 1.83 & 2.90 & 1.83 & 2.00 \\
\hline $\mathrm{Xcp} / \mathrm{Xcpf}$ & 3.00 & 1.75 & 2.00 & 2.50 & $1.50^{* *}$ & $1.50^{*}$ & $1.17^{*}$ & 2.00 \\
\hline Xcpf & 2.00 & 2.00 & 2.00 & 1.50 & 2.00 & 2.50 & 1.67 & 2.17 \\
\hline \multirow[t]{3}{*}{ IIIc. } & $3.00^{* * *}$ & $2.00^{* * *}$ & $2.00^{* *}$ & $1.88^{* * *}$ & $1.83^{* *}$ & 1.50 & 1.33 & 1.33 \\
\hline & $2.00^{* * *}$ & $2.00^{* * *}$ & $2.00^{* *}$ & 1.50 & $2.00^{* *}$ & $2.50^{* * *}$ & $1.67^{*}$ & $2.17^{* *}$ \\
\hline & 1.00 & 1.00 & 1.00 & 1.00 & 1.00 & 1.00 & 1.00 & 1.00 \\
\hline
\end{tabular}

${ }^{1} \mathrm{LV}=\mathrm{La}$ Vega.

${ }^{2}$ Treatment: Bacterial suspensions approximately of $10^{9}$ cells per ml. Proportion of mixed suspensions 1:4 ( $\mathrm{vol} / \mathrm{vol})$; each figure represents the bacterial isolate. $\mathrm{Xcp}=X$. campestris pv. phaseoli, $\mathrm{Xcpf}=X$. campestris pv. phaseoli (fuscans), and $\mathrm{Xcg}=X$. campestris pv. glycines.

${ }^{3}$ In each section the first two treatments were compared with the third using the $t$ test at $p=0.05^{*}$ and $p=0.01^{* *}$. The water-soaked area bordering the scratch was rated as follows: 1 = no water-soaking, 2 = narrow border of water-soaked tissue $\pm 1 \mathrm{~mm}, 3=$ water-soaked area of $2-3 \mathrm{~mm}$ wide, $4=$ water-soaked in round spots, 5 = water-soaked reaching the pod suture.

symptom development when compared with pure suspensions of Xcp and Xcpf, which did not depend on host susceptibility or on the relative proportions of the pathogen in the suspension (table 2).

In $P$. vulgaris leaves, $72 \%$ of the lines which were significantly less susceptible to the Xcp inoculation than the check La Vega, were significantly resistant to the mixed suspensions containing Xcp:Xcpf:Xcg (1:1:1 v:v). The average comparisons of the virulent strains (Xcp and Xcpf) versus the mixed suspensions containing virulent and avirulent $\mathrm{Xcg}$ showed significant differences in the intensity of the symptoms developed on the leaves (table 3). 
TABLE 3.-Responses of bean (Phaseolus vulgaris) lines obtained from CIAT and Cornell inoculated with three isolates of Xanthomonas campestris from Puerto Rico on trifoliolate leaves at flowering stage

\begin{tabular}{|c|c|c|c|c|c|}
\hline \multirow{2}{*}{ Identity } & \multirow{2}{*}{ Pedigree } & \multicolumn{4}{|c|}{ Bacterial isolate $^{1}$} \\
\hline & & $\mathrm{Xcp}$ & Xcpf & $\mathrm{Xcg}$ & Mix \\
\hline \multicolumn{6}{|l|}{ CIAT Lines } \\
\hline BAC 13 & $\mathrm{P} 458 \times \mathrm{P} 698$ & $1.8^{* * 2}$ & 2.0 & 1.0 & $1.0^{* * *}$ \\
\hline BAC 16 & $\mathrm{P} 436 \times \mathrm{P} 698$ & $1.0^{* *}$ & 2.0 & 1.0 & $1.0^{* * *}$ \\
\hline BAC 30 & XAN $47 \times$ G11894 & 2.7 & 2.0 & 1.0 & 1.5 \\
\hline BAC 80 & XAN $449 \times$ XAN 93 & 3.3 & 2.2 & 1.0 & 1.3 \\
\hline BAC 87 & $\mathrm{XAN} 450 \times(\mathrm{P} 436 \times \mathrm{P} 698)$ & $1.5^{* *}$ & $1.0^{* *}$ & 1.0 & $1.0^{* * *}$ \\
\hline BAC 88 & ICA L23 × XAN 93 & 3.7 & 2.0 & 1.0 & 2.0 \\
\hline BAC 90 & $\mathrm{XAN} 930 \times \mathrm{XAN} 93$ & 3.0 & 2.3 & 1.0 & 2.0 \\
\hline BAC 112 & $\begin{array}{l}\text { BAC } 18 \times((\text { P566 } \times \text { P698 }) \times \\
\text { P566 })\end{array}$ & $1.2^{* *}$ & 2.2 & 1.0 & 2.0 \\
\hline $\begin{array}{l}\text { BAC } 105=\mathrm{G} 11509 \times \\
\text { XAN } 93\end{array}$ & XR 6237-8-1-CM-CM & 2.5 & 2.3 & 1.0 & $1.0^{* * *}$ \\
\hline $\begin{array}{l}\text { BAC } 137-\text { G5147 } \times \\
\text { ICA L23 }\end{array}$ & XR 6957-2-1-CM & $1.7^{* * *}$ & 2.2 & 1.0 & 1.3 \\
\hline XAN 93 & $\begin{array}{l}((\mathrm{P} 538 \times \mathrm{P} 684) \times(\mathrm{P} 459 \times \\
\mathrm{P} 567)\end{array}$ & $2.7^{*}$ & 2.8 & 1.0 & 2.5 \\
\hline XAN 1272 & ICA L23 × (P $11 \times$ P635) & $1.5^{* *}$ & 2.0 & 1.0 & $1.0^{* * *}$ \\
\hline XAN 1318 & ICA L23 × XAN 93 & 3.2 & 2.3 & 1.0 & 1.5 \\
\hline \multicolumn{6}{|l|}{ Cornell Lines } \\
\hline $80-4498-4$ & $(79-3865-1 \times 79-3763-1)$ & $1.5^{* *}$ & $1.5^{* *}$ & 1.0 & 1.5 \\
\hline $80-4499-5$ & $(79-3772-2 \times 79-3764-1)$ & $1.5^{* *}$ & $1.6^{*}$ & 1.0 & $1.0^{* * *}$ \\
\hline $80-4512-8$ & $(79-3774-1 \times 79-3812-1)$ & $1.3^{* *}$ & $1.5^{* *}$ & $1.5^{* *}$ & $1.0^{* *}$ \\
\hline $80-4527-6$ & $(79-3775-1 \times 79-3835-1)$ & $1.3^{* *}$ & 1.3 & 1.0 & $1.0^{* * *}$ \\
\hline $80-4530-6$ & $(79-3774 \times 79-3841-1)$ & $1.8^{* *}$ & 2.3 & 1.0 & $1.0^{* * *}$ \\
\hline $80-4531-6$ & $(79-3772-2 \times 79-3843-1)$ & $1.8^{* *}$ & $1.0^{* *}$ & 1.0 & $1.0^{* * *}$ \\
\hline $80-4533-5$ & $(79-3836-1 \times 79-3850-1)$ & $2.0^{* *}$ & $1.2^{* *}$ & 1.3 & $1.0^{* * *}$ \\
\hline $80-4535-6$ & $(79-3764-1 \times 79-3863-1)$ & $1.7^{*}$ & $1.0^{* *}$ & 1.3 & $1.0^{* *}$ \\
\hline $80-4543-4$ & $(79-3889-2 \times 79-3886-3)$ & $2.2^{*}$ & 2.2 & $1.5^{* *}$ & $1.0^{* * *}$ \\
\hline $80-4548-5$ & $(79-3899-1 \times 79-3895-2)$ & 2.8 & 2.0 & 1.0 & 1.3 \\
\hline $80-4552-5$ & $(79-3770-1 \times 79-3903-2)$ & $2.0^{*}$ & 2.3 & 1.3 & $1.0^{* *}$ \\
\hline $80-4774-5$ & $(78-1678-1 \times 78-1633-2)$ & $1.7^{*}$ & 1.8 & 1.0 & 1.5 \\
\hline Control Line & & $2.1^{* *}$ & $1.9^{* *}$ & $1.1^{*}$ & $1.3 \overline{\mathrm{x}}^{3}$ \\
\hline La Vega & & 4.2 & 2.3 & 1.0 & 1.8 \\
\hline
\end{tabular}

${ }^{1} \mathrm{Xcp}=$ Xanthomonas campestris pv. phaseoli, $\mathrm{Xcpf}=\mathrm{X}$. campestris pv. phaseoli (fuscans), $\mathrm{Xcg}=X$. campestris pv. glycines, $\mathrm{Mix}=\mathrm{Xcp}+\mathrm{Xcpf}+\mathrm{Xcg}(1: 1: 1)$.

${ }^{2}$ Readings were compared with the standard La Vega in the columns using the $t$ test at $\mathrm{P}=0.05^{*}$ and $\mathrm{P}=0.01^{* *}$. Scale: $1=$ resistant, $2=$ slightly susceptible, $3=$ moderately susceptible, 4 = susceptible, and $5=$ highly susceptible.

${ }^{3}$ Average comparisons between the bacterial isolates with the mixed suspension using the $t$ test at $\mathrm{P}=0.05^{*}$ and $\mathrm{P}=0.01^{* *}$. 


\section{DISCUSSION}

The heterologous isolate $\mathrm{Xcg}$ reduced the infectivity on pods of $P$. vulgaris and $P$. coccineus when mixed with the virulent isolates $\mathrm{Xcp}$ and $\mathrm{Xcpf}$. This is the first report of such antagonism on pods inoculated with mixed suspensions of virulent and heterologous isolates of $X$. campestris pv. phaseoli. These results partially agree with findings of Leben (7) and Sequeira (13) who showed that the inoculation of a plant with a mixed inoculum of virulent and avirulent or nonpathogenic bacteria usually results in less disease. Mixed suspensions of the virulent isolates were compatible.

The mechanisms by which an isolate of low virulence favors a resistant reaction is not well understood. Possible explanations may be related to bacteriocins or other inhibitor factor production, bacterial attachment to the cell wall and plant products, such as lectins and phytoalexins or inducible compounds $(5,8,9,12,15)$.

In this study, both low and high proportions of the heterologous isolate mixed with the virulent isolates gave some effects on infectivity, indicating that the proportion of the heterologous cells in the suspensions was not involved in the antagonism.

Another explanation for the results obtained may be that Xcg produces a bacteriocin or an inhibitor factor that affects Xcp and Xpf. Abo-El Dahab and El-Goorani (1) studied the antagonism between virulent and avirulent strains of Pseudomonas solanacearum on agar. They found that indoleacetic acid was partially responsible for the antagonism since virulent cells were inhibited at concentrations in which the avirulent continued to grow.

The mechanism of attachment $(5,6,10,13)$ could be different on Xcg and on Xpc and/or Xcpf because mixed suspensions with Xcg showed significant reduction in symptom development on pods but no differences with mixed $\mathrm{Xcp} / \mathrm{Xcfp}$. In this way, antagonism might be related to the degree of attachment or specificity of attachment of homologous (Xcp and $\mathrm{Xcpf}$ ) and heterologous (Xcg) strains of the bacteria on the host. Attachment and envelopment of bacteria occur in many different plant species, such as tobacco leaves infiltrated with $P$. pisi (5), avirulent or heterologous strains of $P$. solanacearum (14), heat killed bacteria (14), or saprophytic bacteria $(2,5,14)$; potato leaves infiltrated with avirulent strains of $P$. solanacearum (15); cucumber leaves inoculated with saprophytic bacteria (14); corn leaves infiltrated with Erwinia carotovora subsp. carotovora (19); bean leaves inoculated with saprophytic bacteria (16); and bean pods tissues with $P$. syringae pv. syringae (3).

The reasons why the isolate of low virulence $\mathrm{Xcg}$ can favor a resistant reaction on pods of $P$. coccineus and $P$. vulgaris and leaves of $P$. vulgaris 
should be fully investigated. For example, correlations between normal lectin content in healthy plants of $P$. vulgaris and $P$. coccineus (leaves and pods) versus plants resistant to bacteria should be clarified.

\section{RESUMEN}

El patógeno bacteriano Xanthomonas campestris pv. phaseoli (E. F. Smith) Dowson, agente causante del tizón común de la habichuela común, Phaseolus vulgaris L., coexiste mundialmente con su cultivo y limita seriamente los rendimientos de la habichuela en los climas tropicales. Se han desarrollado varias técnicas de inoculación para identificar fuentes de resistencia a la infección bacteriana, pero la amplia variedad de cepas ha complicado el trabajo. Algunos investigadores, sin considerar el efecto en la infectividad del inóculo, han usado suspensiones de cepas mezcladas del patógeno.

El objetivo de este estudio fue determinar el efecto en la virulencia de $X$. campestris pv. phaseoli (virulento) cuando se mezcla con un cultivo heterólogo de $X$. campestris pv glycines (baja virulencia) sobre dos especies de Phaseolus. Se encontró que las diferencias producidas por la inoculación de suspensiones mezcladas de $X$. campestris pv. phaseoli dependen de la susceptibilidad del huésped y de la razón o proporción del patógeno en la suspensión. No se encontró efecto sinergístico o antagónico asociado a la combinación de diferentes aislamientos del patógeno. Sin embargo, las suspensiones mezcladas de $X$. campestris pv. phaseoli con el cultivo heterólogo de $X$. campestris pv. glycines mostraron efecto antagónico en el desarrollo de síntomas en las vainas. Estos sintomas no dependen de la susceptibilidad del huésped ni de la proporción de cada patógeno en la suspensión bacteriana. Los resultados indican que en una suspensión bacteriana mezclada con diferentes aislamientos no siempre predomina la reacción al de más alta virulencia.

\section{LITERATURE CITED}

1. Abo-El-Dahab, M. K. and El Goorani, M. A., 1969. Antagonism among strains of Pseudomonas solanacearum. Phytopathology 59: 1005-007.

2. Cason, E. T., Richardson, P. E., Essenberg, M. K., Brinkerhoff, L. A., Johnson, W. M. and Venere, R. J., 1978. Ultrastructural cell wall alterations in immune cotton leaves inoculated with X. malvacearum. Phytopathology 68: 1015-021.

3. Daub, M. and Hagedorn, D., 1979. Resistance of Phaseolus line WBR 133 to Pseudomonas syringae. Phytopathology 69: 946-51.

4. Ekpo, J. A. Ephraim, 1975. Pathogenic variation in common (Xanthomonas phaseoli) and fuscous (X. phaseoli var. fuscous) bacterial blight of beans, P. vulgaris L. Ph.D. Thesis, Michigan State University, East Lansing.

5. Goodman, R. N., Huang, P. Y. and White, J. A., 1976. Ultrastructural evidence for immobilization of an incompatible bacterium, Pseudomonas pisi, in tobacco leaf tissue, Phytopathology 66: 754-64.

6. Klement, Z., Farkas, G. L. and Lovrekovich, L., 1964. Hypersensitive reaction induced by photopathogenic bacteria in the tobacco leaf, Phytopathology 54: 474-77. 
7. Leben, C., 1965. Epiphytic microorganisms in relation to plant diseases, Ann. Rev. Phytopathology 3: 209-30.

8. Pueppke, S. G., Wolfgang, D. B., Keegstra, K. and Ferguson, A. L., 1978. Role of lectins in plant microorganism interactions. II. Distribution of soybean lectin in tissues of Glycine max (L.) Merr. Plant Physiol. 61: 779-84.

9. Pusziai, A., 1981. Seed lectins: structure, distribution and possible roles. International Symposium Seed Proteins. Summary. France. September 22-4.

10. Roebuck, P., Sexton, R. and Mansfield, J. W., 1978. Ultrastructural observations on the development of the hypersensitive reaction in leaves of Phaseolus vulgaris cv. Red Mexican inoculated with Pseudomonas phaseolicola (race 1). Physiol. Plant Pathol, 12: 151-57.

11. Rudolf, K., 1981. In Methodology for evaluating plant resistance to bacterial pathogens, G. L. Ercolani. Fifth International Conference on Plant Pathogenic Bacteria. CIAT, Colombia.

12. Sequeira, L., 1978. Lectins and their role in host pathogen specificity, Ann. Rev. Phytopathology 16: 453-81.

13. — 1979. The acquisition of systemic resistance by prior inoculation in recognition and specificity in plant-host parasite interactions, T. M. Daly and I. Uritani, Eds, Japan. Science Society Press, Tokyo. p. 231-251.

14. — Gaard, G. and De Zoeten, G. A., 1977. Interactions of bacteria and host cell walls: its relation to mechanism of induced resistance, Physiol. Plant Pathol. 10: 43-50.

15. — and Graham, T. L., 1977. Agglutination of avirulent strains of $P$. solanacearum by potato lectin, Physiol. Plant Pathol. 11: 43-54.

16. Sing, V. O. and Schroth, M. N., 1977. Bacteria-plant cell surface interaction: Active immobilization of saprophytic bacteria in plant leaves, Science 197: 759-61.

17. Smidt, M. L. and Vidaver, A. K., 1982. Bacteriocin production by Pseudomonas syringae Ps. W-1 in plant tissue, Can. J. Microbiol. 28: 600-04.

18. Teliz-Ortiz, M. and Burkholder, W. H., 1960. A strain of Pseudomonas fluorescens antagonistic to $P$. phaseolicola and other bacterial plant pathogens, Phytopathology 50: $119-23$.

19. Victoria, J. I., 1977. Resistance in corn (Zea mays L.) to bacterial stalk rot in relation to virulence of strains of Erwinia chrysanthemi, Ph.D. thesis, University of Wisconsin, Madison.

20. Zapata, M., 1982. Callus formation on bean pods (Phaseolus vulgaris L.) as a response to inoculation with several strains of Xanthomonas phaseoli (E. F. Smith) Dowson. (Abstr.) Phytopathology 72: 174.

21. — and Freytag, G. F., 1982. Phaseolus germ plasm resistant to six strains of Xanthomonas in Puerto Rico. (Abstr.) Phytopathology 72: 174.

22. —- Freytag, G. F. and Wilkinson, R. E., 1982. Techniques recommended for the determination of resistance in Phaseolus to Xanthomonas. (Abstr.) Phytopathology 72: 174 . 